\title{
LATEX SEBAGAI ALTERNATIF APLIKASI UNTUK PENULISAN JURNAL COMTECH
}

\author{
Bayu Kanigoro; Jurike V. Moniaga \\ Jurusan Teknik Informatika, Fakultas Ilmu Komputer, Bina Nusantara University \\ Jln. K.H. Syahdan No. 9, Palmerah, Jakarta 11480 \\ bkanigoro@binus.edu; jurike@binus.edu
}

\begin{abstract}
This paper presents how to use TeX /LaTeX as an altenative for writing ComTech journal by explaining LaTeX commandos which will be used to form an article from title to introduction based on ComTech journal requirement. The result presents an article to be compiled from TeX/LaTeX intepreter is nearly has same layout as presented from word processor.
\end{abstract}

Keywords: TeX, LaTeX, typesetting, word processor, programming language

\begin{abstract}
ABSTRAK
Tulisan ini akan memaparkan penggunaan TeX/LaTeX sebagai alternatif dalam penulisan jurnal ComTech dengan menjelaskan instruksi-instruksi LaTeX yang digunakan untuk mengatur tampilan judul tulisan sampai dengan tubuh tulisan sesuai dengan spesifikasi yang telah ditetapkan jurnal ComTech. Hasil dari kompilasi tersebut mendekati susunan format yang telah ditetapkan oleh jurnal ComTech yang dipersiapkan untuk pengolah kata Word Processor.
\end{abstract}

Kata kunci: TeX, LaTeX, typesetting, pengolah kata, bahasa pemrograman 


\section{PENDAHULUAN}

Pengolah kata (word processor) adalah suatu aplikasi komputer yang digunakan untuk menghasilkan tulisan tercetak dengan melakukan komposisi, pengeditan, pengaturan dan termasuk pencetakan tulisan. Konsep yang digunakan pada pengolah kata seperti yang di paparkan oleh (Cottrell, 1999) adalah dengan menggunakan dua metoda secara bersamaan dalam penyusunan tulisan yang antara lain pertama melakukan komposisi tulisan dalam penurunan ide, pemilihan kata dan penyusunan logika penulisan secara runtut. Kedua, melakukan pengaturan tampilan tulisan yang mempunyai tugas seperti pemilihan karakter, penyusunan margin, catatan kaki, header, dan sebagainya.

Dari sisi penggunaan, pengolah kata memberikan kemudahan dalam penggunaan konsep WYSIWYG dalam editornya karena dengan konsep tersebut, pemakai akan mendapatkan persepsi apa yang dilihat di monitor akan sama hasilnya bila dicetak di mesin pencetak. Dengan konsep tersebut memungkinkan aplikasi dapat digunakan untuk pembuatan tulisan oleh berbagai lapisan pengguna mulai dari yang paling mahir sampai pemula. Di samping kemudahan yang ditawarkan oleh aplikasi pengolah kata, aplikasi tersebut hanya efektif bila digunakan untuk mengkomposisi tulisan yang relatif sederhana dan pendek. Bila tulisan tersebut mempunyai banyak gambar, grafik dan tabel maka waktu pemrosesan tulisan tersebut dengan menggunakan pengolah kata akan jauh lebih lambat. Kelemahan yang lain adalah bila tulisan tersebut mempunyai notasi-notasi sains dan matematika maka kualitas hasil penulisan notasi tersebut bila menggunakan pengolah kata menjadi tidak memuaskan.

Menurut Cottrell (1999), penggunaan pengolah kata juga menyebabkan distraksi karena penulis hanya bertanggung-jawab dalam komposing tulisan sedangkan pengaturan tampilan tulisan adalah bukan pekerjaan utama penulis. TeX (disebut tech dan dieja Tau-Epsilon-Chi) (Salzberg, 2005) adalah sistem setter tulisan typesetting yang dibuat oleh pakar komputer Donald E. Knuth pada akhir dekade 70-an yang mempunyai fungsi hampir mirip dengan pengolah kata tetapi mempunyai perbedaan yang cukup mendasar diantara keduanya dalam penyusunan tulisan. Penyusunan tulisan menggunakan TeX memerlukan pemisahan antara kegiatan komposisi tulisan dengan kegiatan pengaturan tampilan tulisan sedangkan pengolah kata menyatukan kedua kegiatan tersebut dalam penyusunan tulisan. Kekurangan TeX adalah curamnya kurva belajar untuk mempelajarinya yang disebabkan untuk menyusun sebuah tulisan dengan TeX memerlukan pemahaman perintah-perintah dasar TeX.

Tulisan ini akan memaparkan bagaimana menulis dengan menggunakan TeX yang diharapkan mempunyai manfaat sebagai acuan untuk penulisan karya ilmiah jurnal ComTech Universitas Bina Nusatara. Sistematika dari tulisan ini adalah bab Penyusunan Tulisan yang membahas bagaimana melakukan penyusunan judul sampai dengan tubuh tulisan dengan mengikuti standar jurnal ComTech. Dilanjutkan dengan bab Hasil yang akan memaparkan hasil kompilasi yang telah dijelaskan pada bab Penyusunan Tulisan dan ditutup dengan bab Kesimpulan.

\section{METODE}

Penyusunan tulisan dengan pengolah kata seperti Microsoft Word ${ }^{\mathrm{TM}}$ sudah banyak diketahui secara umum oleh para pengguna komputer awam. Dengan konsep WYSIWYG, penyusunan tulisan menjadi sangat mudah. Bertolak-belakang dengan TeX. Meskipun sudah ada antar-muka dengan konsep WYSIWYG (Quill, 1999), TeX adalah markup language seperti HTML. Urutan langkah dalam penyusunan tulisan dengan TeX (Salzberg, 2005) adalah tulisan yang akan dicetak diberikan perintahperintah TeX yang menjadi berkas sumber TeX. Berkas sumber tersebut kemudian diintepretasi oleh 
interpreter TeX yang akan menghasilkan tulisan final tersebut dalam bentuk DVI, PostScript, PDF. Jadi proses penulisan dengan TeX adalah mulai dari penulisan, kompilasi, hasil, perbaikan kesalahan, rekompilasi dan terus dilakukan sampai didapat hasil yang final.

LaTeX adalah kumpulan dari fungsi-fungsi makro yang ditujukan untuk mempermudah dalam penggunaan TeX yang dibuat oleh Leslie Lamport (Lamport, 1986). Fungsi-fungsi tersebut berisi perintah-perintah TeX yang disusun untuk mengerjakan kegiatan-kegiatan yang sering digunakan dalam penyusunan tulisan. Jadi untuk melakukan satu kegiatan dimana diperlukan beberapa baris perintah TeX bisa diselesaikan dalam satu baris perintah macro LaTeX. Selain itu LaTeX juga mempunyai format-format standar yang digunakan untuk publikasi ilmiah ternama seperti IEEE dan ACM dimana karya-karya ilmiah yang akan dipublikasikan harus mengikuti format tersebut sehingga hasil akhirnya adalah jurnal atau prosiding dengan susunan yang telah distandarisasi.

Di dalam penyusunan sebuah tulisan dengan LaTeX, setiap tulisan dimulai dengan instruksi Idocumentclass. Instruksi ini digunakan untuk menentukan style dari tulisan yang akan digunakan. LaTeX menyediakan tiga bentuk style dasar dalam parameter kelasnya antara lain report, article, dan book. Parameter yang lain dalam kelas tersebut adalah ukuran huruf dan kertas. LaTeX mempunyai tiga ukuran standar untuk ukuran huruf yaitu 10pt, 11pt dan 12pt dan untuk ukuran kertas, LaTeX menyediakan ukuran kertal "letter", "legal", "executive”, A4, A5, dan B5 dengan parameter secara berurutan adalah letterpaper, legalpaper, executivepaper, a4paper, a5paper, dan b5paper.

Pengaturan margin dari di dalam dokumen menggunakan paket geometry dengan memberikan opsi-opsi top, bottom, left, right yang secara berurutan mementukan margin atas, bawah, kiri dan kanan. Bentuk formal dari paket tersebut adalah,

\section{Iusepackage $[$ top $=\ldots$, bottom $=\ldots$, left $=\ldots$, right $=\ldots]\{$ geometry $\}$}

Satuan panjang yang digunakan untuk menentukan margin menggunakan millimeter (mm), inch (in) dan point (pt). Penempatan instruksi lusepackage dilakukan setelah \documentclass tetapi sebelum begin\{document\}. Instruksi berikutnya adalah begin\{document\} dan diakhiri oleh lend\{document\}. Instruksi Jbegin\{document\} menyatakan awal tulisan dan instruksi lend\{document\} menyatakan akhir dari tulisan dan antara instruksi inilah tubuh dari tulisan yang akan disusun itu diletakkan. Instruksi ini disebut juga document environment (lingkungan dokumen).

Untuk penulisan judul ada dua pilihan yang bisa dilakukan yaitu dengan menggunakan instruksi pembuat judul dan manual. Pilihan pertama adalah dengan menggunakan instruksi pembuat judul. Dengan menggunakan pilihan ini maka format tampilan judul di dalam LaTeX sudah ditentukan di dalam style yang dipilih di \documentclass dan penulis cukup dengan menggunakan instruksi \title, lauthor, Idate dan Imaketitle. Instruksi \title digunakan untuk mencetak judul pada tulisan, instruksi lauthor digunakan untuk mencetak nama penulis, instruksi \date digunakan untuk mencetak tanggal dan instruksi \maketitle digunakan untuk mengkomposisi judul. Penempatan instruksi \title, lauthor dan Idate diletakkan sebelum instruksi lingkungan dokumen dan instruksi Imaketitle diletakkan didalam instruksi lingkungan dokumen. Sayangnya pilihan ini tidak bisa digunakan karena hasil dari instruksi tersebut tidak memenuhi syarat format yang telah ditetapkan oleh penerbit. Kecuali bila dilakukan pembuatan style yang mengikutinya. Pilihan kedua adalah dengan cara manual. Dengan cara ini, tampilan judul diletakkan di tengah dengan menggunakan instruksi \centerline. Kemudian ukuran huruf pada judul diperbesar dengan menggunakan instruksi \Large yang akan menghasilkan huruf dengan rasio $1.273 \mathrm{x}$ dari ukuran huruf default $11 \mathrm{pt}$ yang dideklarasikan sebelumnya di Idocumentclass. Judul juga ditebalkan dengan menggunakan instruksi \textbf.

Untuk penulisan nama, menggunakan instruksi \centerline untuk memposisikan nama tepat 
ditengah. Menurut standar ComTech, penulisan nama menggunakan huruf dengan ukuran 12pt yang dapat dipenuhi dengan menggunakan instruksi large yang akan menghasilkan huruf dengan rasio 1.09x dari ukuran huruf default 11pt yang dideklarasikan sebelumnya di \documentclass.

Penulisan institusi atau afiliasi penulis menggunakan instruksi Icenterline untuk memposisikan tampilan di tengah halaman. Bila nama institusi lebih dari satu baris, maka instruksi Icenterline harus ditulis di setiap baris. Metoda yang lain adalah dengan mengunakan lingkungan begin\{center\} dan diakhiri dengan lend\{center\}. Bia menggunakan lingkungan tersebut, maka setiap akhir baris di dalam lingkungan cukup diberikan instruksi \ yang menginstruksikan bahwa baris baru diperlukan setelah instruksi tersebut.

Jarak spasi antara judul, nama penulis, dan nama institusi masing-masing dipisahkan dua spasi menurut standar jurnal ComTech. TeX tidak otomatis memberikan dua spasi hanya dengan memberikan dua buah simbol CR seperti pada pengolah kata karena TeX menganggap satu atau lebih simbol CR adalah satu baris baru. Solusi dari permasalahan ini adalah dengan memberikan instruksi Ivspace dengan parameter jarak vertikal. Nilai jarak vertikal dapat ditentukan dengan menggunakan patokan ukuran huruf yang ditentukan sebelumnya di \documentclass dikali dengan jumlah spasi. Contoh, bila ukuran huruf adalah 10pt dan spasi yang diinginkan adalah dua maka nilai jarak vertikal yang diberikan adalah 20pt.

Penulisan abstrak yang dilakukan pertama kali adalah dengan menuliskan judul kata "ABSTRAK" di posisi tengah halaman sesuai dengan format jurnal ComTech. Instruksi yang digunakan untuk memposisikan kata "ABSTRAK" adalah Icenterline diikuti Itextbf untuk menebalkan kata tersebut. Ukuran huruf yang diminta oleh format ComTech adalah 13pt yang bisa diselesaikan dengan instruksi $\backslash$ Large.

Di dalam abstrak disyaratkan untuk ditulis dengan menggunakan huruf miring menurut format ComTech. Maka instruksi Itextit digunakan untuk penulisan abstrak menurut syarat tersebut. Kemudian jarak antara kata "ABSTRAK" dengan tubuh abstrak dipisah jarak dua spasi yang dapat diselesaikan dengan instruksi Ivspace dengan parameter yang berisi ukuran huruf default dikali dengan dua.

Kata kunci ditulis setelah tubuh abstrak dengan jarak satu spasi dan ditulis miring dan tebal untuk kalimat "Kata kunci : ". Instruksi yang digunakan adalah \textbf untuk menebalkan kalimat "Kata kunci:" dan Itextit untuk memiringkannya. Ivspace juga digunakan untuk memberikan jarak spasi antara tubuh abstrak selebar satu spasi dengan kata kunci dan antara kata kunci dengan judul "PENDAHULUAN" selebar dua spasi. Instruksi Inoindent digunakan untuk menghapus indentasi paragraf yang terjadi secara otomatis ketika kata kunci masuk ke baris baru.

Tubuh tulisan dalam jurnal ComTech dimulai dari sub judul pendahuluan sampai dengan kesimpulan. Sub judul di dalam tubuh tulisan seluruhnya menggunakan huruf kapital dan diposisikan di tengah halaman dengan menggunakan instruksi \centerline, ditebalkan dengan menggunakan Itextbf dan dibesarkan dengan instruksi \Large. Jarak antara sub judul dengan isi materi dipisah dengan dua spasi dengan menggunakan instruksi Ivspace. Isi materi menggunakan ukuran huruf standar yang telah ditetapkan sebagai default.

\section{HASIL DAN PEMBAHASAN}

Hasil dari tulisan yang dipaparkan disini menggunakan huruf 11pt, ukuran kertas A4, dan menggunakan style "article” yang didefinisikan di kelas dokumen. Deklarasi kelas dari dokumen 
tersebut adalah:

\documentclass [11pt] \{article\}

Tampilan LaTeX akan ditulis dengan instruksi $\backslash$ LaTeX dan $\backslash$ TeX untuk menampilkan logo LaTeX dan TeX. Jurnal ComTech (Redaksi, 2010) mensyaratkan ukuran margin atas 1 inch, bawah 1 inch, kiri 1.25 inch dan kanan 1 inch.

Jusepackage [top=1.0in, bot tom=1. 0 in, left=1.25in, right=1. 0 in] $\{$ geometry\}

Pada hasil kompilasi judul ditulis dengan metoda kedua yaitu dengan cara tampilan judul diletakkan di tengah dengan menggunakan instruksi Icenterline.

\section{\centerline $\{\backslash$ textbf $\{\backslash$ Large \LaTeX SEBAGAI ALTERNATIF APLIKASI UNTUK PENULISAN JURNAL COmmIT \}\}}

Di sini judul ditebalkan dengan menggunakan instruksi \textbf kemudian diperbesar dengan instruksi Large yang akan menghasilkan ukuran huruf 14pt. Jurnal ComTech mensyaratkan judul tulisan ditulis dengan huruf kapital semuanya kecuali kata-kata yang terdapat dalam judul tidak bisa disubtitusikan. Penulisan nama pada hasil kompilasi menggunakan instruksi \centerline yang dipisah dengan Ivspace.

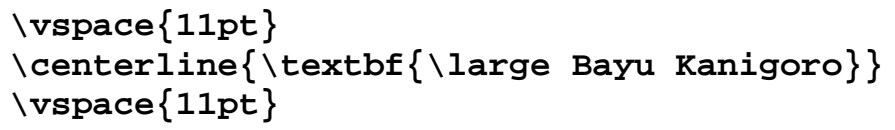

Instruksi Ivspace diisi dengan parameter 11pt yang berarti diberikan jarak vertikal dengan besaran 11pt sama dengan satu spasi dengan ukuran huruf default 11pt. Afiliasi ditulis dengan mengunakan lingkungan \begin\{center\} dan diakhiri dengan lend\{center\} dengan menggunakan instruksi "I|" } untuk membuat baris baru.

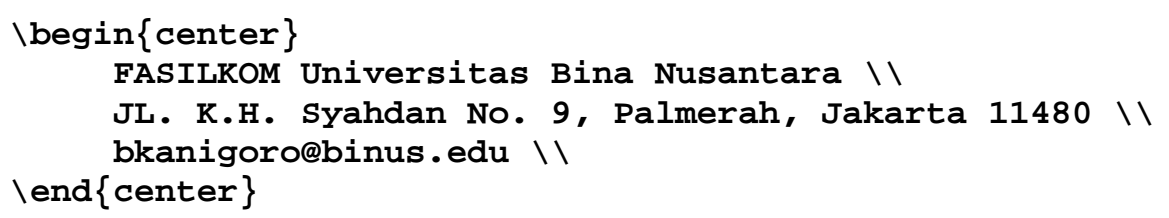

Penulisan judul abstrak menggunakan instruksi Icenterline dipisah dengan instruksi Ivspace\{11pt\} untuk memberikan jarak satu spasi.

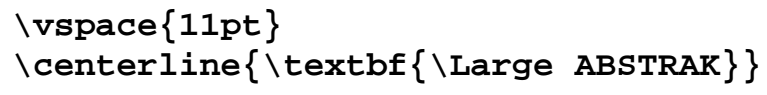

Penulisan isi abstrak menggunakan instruksi \textit dan instruksi \vspace\{11pt\} digunakan untuk memberikan jarak satu spasi beserta instruksi Inoindent digunakan untuk menghilangkan paragraf pada tulisan Kata Kunci. Itextit digunakan untuk memiringkan kata kunci dan instruksi Itextbf digunakan untuk menebalkan kalimat “Kata Kunci”. Instruksi Ivspace\{22pt\} digunakan untuk memberikan jarak dua spasi antara kata kunci dengan judul pendahuluan.

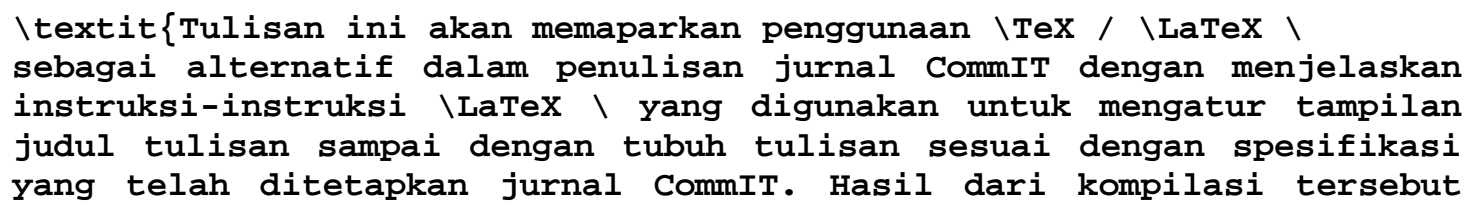


mendekati susunan format yang telah ditetapkan oleh jurnal CommIT yang dipersiapkan untuk pengolah kata Word Processor.\}

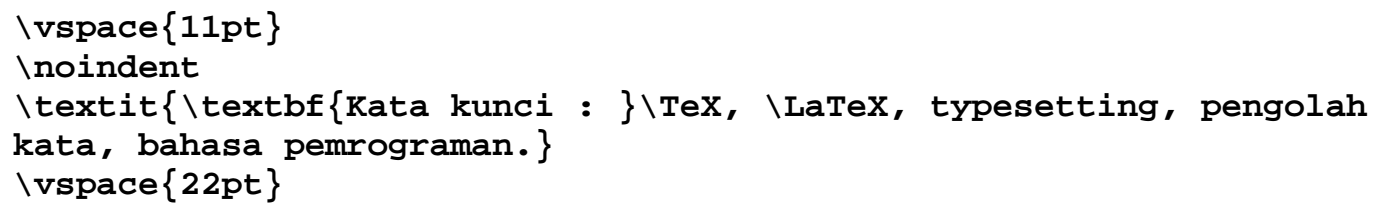

\title{
AT $T_{\mathrm{E}} \mathrm{X}$ SEBAGAI ALTERNATIF APLIKASI UNTUK PENULISAN JURNAL CommIT
}

\author{
Bayu Kanigoro \\ FASILKOM Universitas Bina Nusantara \\ JL. K.H. Syahdan No. 9, Palmerah, Jakarta 11480 \\ bkanigoro@binus.edu
}

\begin{abstract}
ABSTRAK
Tulisan ini akan memaparkan penggunaan $T_{E} X / E T_{E} X$ sebagai alternatif dalam penulisan jurnal CommIT dengan menjelaskan instruksi-instruksi ${ }^{A} T_{E} X$ yang digunakan untuk mengatur tampilan judul tulisan sampai dengan tubuh tulisan sesuai dengan spesifikasi yang telah ditetapkan jurnal CommIT. Hasil dari kompilasi tersebut mendekati susunan format yang telah ditetapkan oleh jurnal CommIT yang dipersiapkan untuk pengolah kata Word Processor.

Kata kunci : $T_{E} X, E_{T} T_{E} X$, typesetting, pengolah kata, bahasa pemrograman.
\end{abstract}

\section{PENDAHULUAN}

Pengolah kata (Word Processor) adalah suatu aplikasi komputer yang digunakan untuk menghasilkan tulisan tercetak dengan melakukan komposisi, pengeditan, pengaturan dan termasuk pencetakan tulisan. Konsep yang digunakan pada pengolah kata seperti yang di paparkan oleh [Cottrell, 1999] adalah dengan menggunakan dua metoda secara bersamaan dalam penyusunan tulisan yang antara lain adalah :

1. Melakukan komposisi tulisan dalam penurunan ide, pemilihan kata dan penyusunan logika penulisan secara runtut.

2. Melakukan pengaturan tampilan tulisan yang mempunyai tugas seperti pemilihan karakter, penyusunan margin, catatan kaki, header, dan sebagainya.

Gambar 1 Hasil Kompilasi

Judul pendahuluan ditulis dengan instruksi Icenterline dan instruksi Itextbf untuk menebalkan. Instruksi \Large akan menghasilkan .Instruksi Ivspace\{22pt\} untuk memberikan jarak dua spasi antara judul dengan tubuh pendahuluan.

\section{\centerline $\{\backslash$ textbf $\{\backslash$ Large PENDAHULUAN $\}\}$ \\ Ivspace $\{22 \mathrm{pt}\}$}

Penomoran item di dalam tubuh pendahuluan menggunakan instruksi lbegin\{enumerate\} dan ditutup dengan lend\{enumerate\} yang di dalam lingkungan tersebut berisi instruksi litem untuk penomoran.

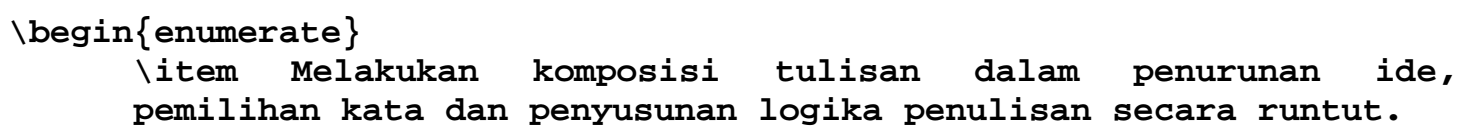




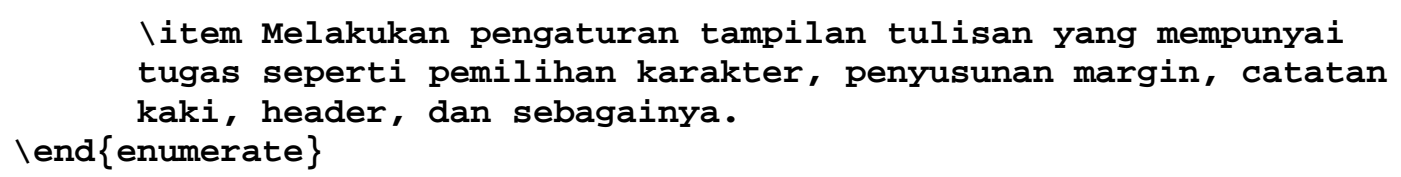

Di dalam lingkungan enumerate, nomor urut ditentukan secara otomatis dimana nomer pertama dmulai dari instruksi litem yang paling dekat dengan instruksi begin\{enumerate\} dan diakhiri dari instruksi litem yang paling dekat dengan instruksi lend\{enumerate\}.

\section{SIMPULAN}

Dari hasil kompilasi yang dipaparkan pada sub-bab hasil dapat disimpulkan bahwa untuk penulisan jurnal ComTech dapat menggunakan LaTeX sebagai alternatif aplikasi yang diperlihatkan pada hasil kompilasi mendekati dengan standar jurnal ComTech yang disusun dengan menggunakan pengolah kata. Disamping itu dengan pemisahan antara kompilasi tulisan dengan pengaturan tulisan tidak akan menyebabkan distraksi penulis dalam mengeluarkan ide-ide kedalam tulisannya. Pengembangan selajutnya adalah penulisan referensi dengan menggunakan BibTeX sebagai basis data dalam penulisan.

\section{DAFTAR PUSTAKA}

Cottrell, A. (1999). Word Processor: Stupid and Ineficient, from http://ricardo.ecn.wfu.edu/ cottrell/wp.html

Lamport, L. (1986). LaTeX User's Guide and Document Reference Manual. Reading, MA: AddisonWesley.

Quill, U. (1999). Introduction to LyX: Make working with LaTex easierusing the WYSIWYG editor LyX. Linux J. 1999, 57es (Jan. 1999), 6.

Redaksi. (2010). Pedoman penulisan. ComTech, 1.

Salzberg, B., \& Murphy, T. (2005). LaTeX: When Word Fails You. In Proceedings of the 33rd Annual ACM SIGUCCS Fall Conference (Monterey, CA, USA, November 06 - 09, 2005). SIGUCCS '05. ACM, New York, NY, 241-243. DOI= http://doi.acm.org/10.1145/1099435.1099490 